\title{
Base Quaternary in the Danish parts of the North Sea and Skagerrak
}

\author{
Tove Nielsen, Anders Mathiesen and Malene Bryde-Auken
}

Over the years, several maps of the base Quaternary surface of the Danish area have been published. However, the maps have either been local in character (e.g. Håkansson \& Pedersen 1992; Huuse et al. 2001) or have concentrated on special topics such as tunnel valleys (e.g. Huuse \& Lykke-Andersen 2000) or glaciotectonic features (e.g. Klint \& Pedersen 1995; Andersen et al. 2005). The only published map of a more regional character is that of Binzer \& Stockmarr (1994) that covers onshore Denmark and eastern Danish waters. Here we present for the first time a regional map of the base Quaternary surface for the entire Danish sector of the North Sea and Skagerrak based on interpretations of reflection seismic data at the Geological Survey of Denmark and Greenland (GEUS) (Fig. 1). The new map has been depth-converted and merged with the onshore map of Binzer \& Stockmarr (1994) and thus the first map covering the entire Danish land and sea areas has been compiled.

The definition of the base Quaternary is a current issue of debate. In this article, we follow Gradstein et al. (2004) who place the base Quaternary at base Gelasian, which is dated to 2.59 Ma. In parts of the studied area, glacial tectonic features in the form of thrust complexes can be seen on the seismic data. Here the base Quaternary surface has been placed at the base of the dislocated thrust units, corresponding to the basal décollement horizon.

The base Quaternary surface is of both academic and practical interest. The depth to the base Quaternary surface and its morphology are of interest to the understanding of

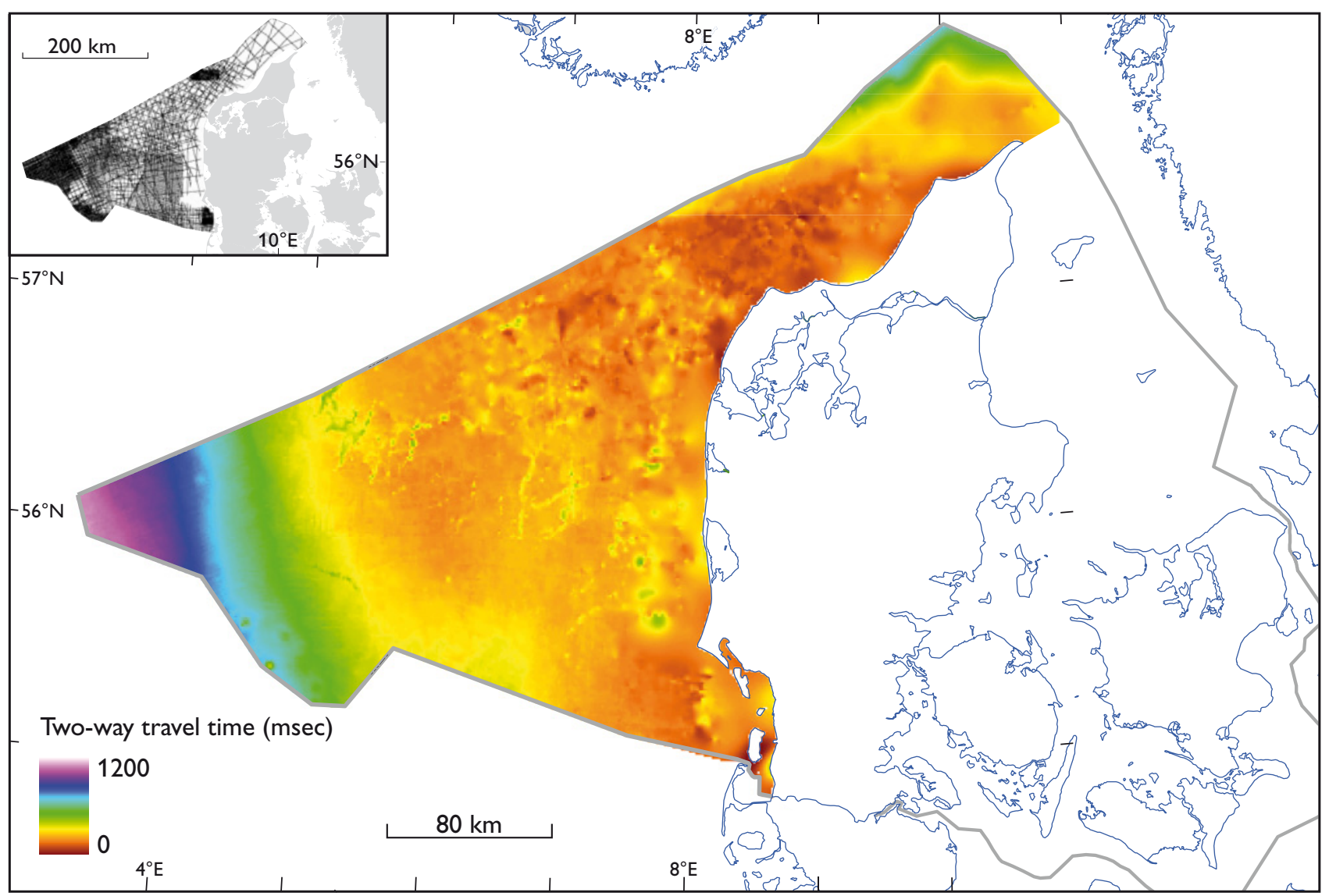

Fig. 1. The base Quaternary surface in the Danish sector of the North Sea and Skagerrak. The depth to the surface is shown in seismic two-way travel time in milliseconds below sea surface. The inset shows the line density of the seismic database. 

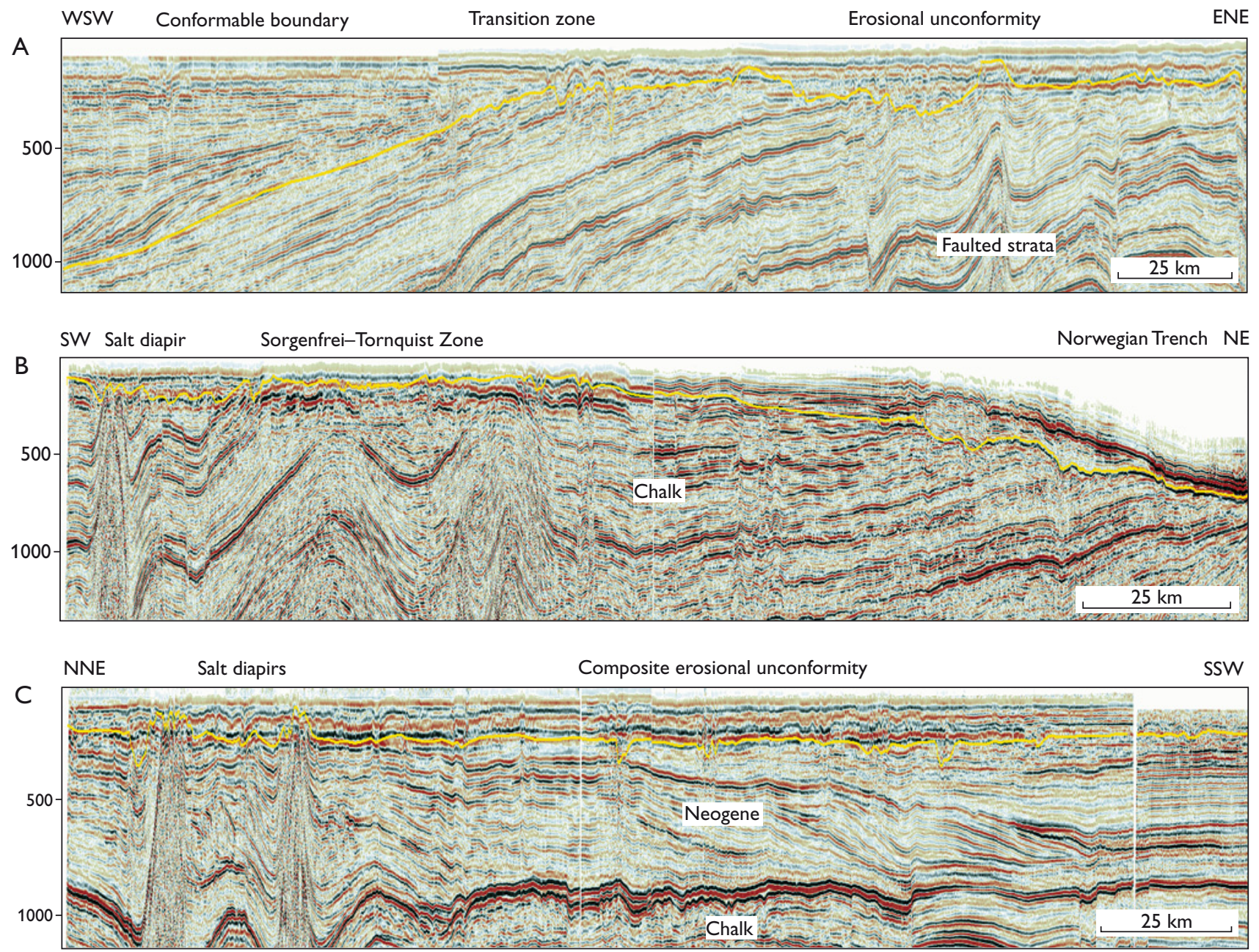

Fig. 2. Composite seismic profiles with the base Quaternary surface marked in yellow. The location of the profiles is shown in Fig. 3. A: Cross-section of the Danish North Sea sector. In the eastern part, the base Quaternary is seen as an erosional unconformity that cuts into mid- and late Cenozoic delta deposits. Towards the west, the base Quaternary becomes conformable with the underlying Lower Pliocene delta clinoforms. B: Cross-section of Skagerrak where the Quaternary deposits are relatively thin. The Quaternary is underlain by chalk and marks a major hiatus most likely formed by erosion during multiple glaciations. The high-lying chalk area towards the south is coincident with the Sorgenfrei-Tornquist Zone. Towards the north, the base Quaternary surface deepens and dips towards the Norwegian Trench. C: Cross-section of the Danish North Sea sector illustrating how in large parts of the North Sea the base Quaternary marks a change in depositional style from prograding pre-Quaternary delta deposits to aggradation or chaotic Quaternary till deposits. Towards the north, the shape of the base Quaternary surface implies that in this area the salt domes have been active during the Quaternary.

the Quaternary development of the region, but are also important in relation to offshore constructions such as oil and gas platforms, pipelines and wind mills.

\section{Database and mapping procedure}

The present seismic interpretation of the base Quaternary surface in the North Sea and Skagerrak (Fig. 1) forms part of a larger North-West Europe mapping project (Petroleum geological atlas of the southern Permian Basin area - SPBA), and the mapping is based on GEUS' digital 2D reflection seismic and well databases. The seismic interpretation is gridded in a $1000 \times 1000 \mathrm{~m}$ grid and subsequently depth-converted using a linear time-depth function, ensuring that the resultant depth in metres fits available well data. In order to merge the new map with the pre-existing onshore map (Binzer \& Stockmarr 1994), the latter has likewise been gridded into $1000 \times 1000 \mathrm{~m}$ grids. To complete the composite map, a new seismic interpretation of the southern part of Bælthavet has been carried out, following the same interpretation procedure as for the North Sea and Skagerrak areas.

\section{The base Quaternary surface}

Using the $2.59 \mathrm{Ma}$ age rather than the so far official $1.8 \mathrm{Ma}$ age for the base of the Quaternary, only causes differences in the western North Sea where the mapped surface is deeply buried and lies conformably on Pliocene deltaic sediments 
Fig. 3. Overview map showing areas and outline of features mentioned in the text. Also shown are the positions of the seismic profiles in Fig. 2. The inset shows the main structural elements and outline of shallow basement.

(Figs 1, 2). To the east, the base of the Quaternary shallows and becomes an erosional unconformity that cuts into pre-Quaternary deposits (Figs 1, 2). The transition zone from the conformable boundary to the erosional surface is marked in Fig. 3. The hiatus between the Quaternary and the underlying strata becomes greater towards the east (Rasmussen et al. 2005), and over large areas the base Quaternary surface is underlain by chalk (Fig. 2). This setting is a consequence of Neogene uplift and subsequent erosion.

The amount of glacial erosion during the Quaternary has been estimated to about one fifth of the total Neogene and Quaternary erosion (Japsen et al. 2002). The base Quaternary erosional surface east of the transition zone is most likely to be a composite unconformity created during multiple glaciations. West of the transition zone, the lower Quaternary deposits form a delta complex, and glacial erosion is only seen within the upper Quaternary deposits in the form of tunnel valleys and internal erosional surfaces (Fig. 2A). This depositional pattern shows that during the early Quaternary the glaciations did not extend into the central North Sea, and that full glaciation with grounding ice sheets did not occur in this area until later in the Quaternary.

In the north-eastern Danish North Sea, the base Quaternary surface displays an irregular morphology with several isolated, circular highs (Figs 1, 3). In the westernmost part of the Danish North Sea three similar highs are also seen. This pattern is the result of salt doming that was active during the Quaternary (Fig. 2C). Tunnel valleys occur in association with some of the salt domes, but few of them affect the base Quaternary surface. In the south-western Danish North Sea, the base Quaternary surface shows two elongated areas with depressions parallel to the coast of Jylland (Figs 1, 3). Here glaciotectonic deformation has taken place, resulting in the formation of major thrust complexes involving preQuaternary deposits with deep-lying décollement horizons. The trend of the thrust complexes and the internal pattern of the thrust faults indicate that they were formed by westwardmoving ice.
In the central Danish North Sea, an E-W-trending belt of narrow, elongated incisions is seen in the base Quaternary surface (Figs 1, 3). This is a network of deep tunnel valleys that cuts into the pre-Quaternary deposits. The valleys have the same overall N-S trend, suggesting that they were formed below ice advancing over the area from the north. Some of the valleys are spatially associated with old fault systems (Fig. $2 \mathrm{~A}$ ), but usually there appear to be no pre-Quaternary features that can explain their location. It is worth noting that only few tunnel valleys incise the base Quaternary surface outside this approximately $80 \mathrm{~km}$ wide belt (Fig. 1), and hardly none on top of the Ringkøbing-Fyn High (Fig. 3, inset).

In most of the Skagerrak area, the Quaternary deposits rest unconformably on Cretaceous chalk (Figs 2B, 3). In the Sorgenfrei-Tornquist Zone in southern Skagerrak (Fig. 3, inset), the base Quaternary surface is relatively shallow due to up-thrusted chalk. Towards the north, the surface deepens and dips in the direction of the Norwegian trench (Figs 1,2).

Figure 4 shows the base Quaternary composite depth map created by merging existing and new interpretations (see above). This map has been produced in order to place the interpretation of the North Sea and Skagerrak areas into a broader context. Differences in databases and mapping procedure have caused some discrepancies in the composite map. Nevertheless, some interesting observations can be made. The belt of distinct N-S-trending tunnel valleys incising the base Quaternary surface in the North Sea continues onshore in central Jylland, where it is cut by a N-S-trending belt of shallower, E-W-trending tunnel valleys (Figs 3, 4). The 


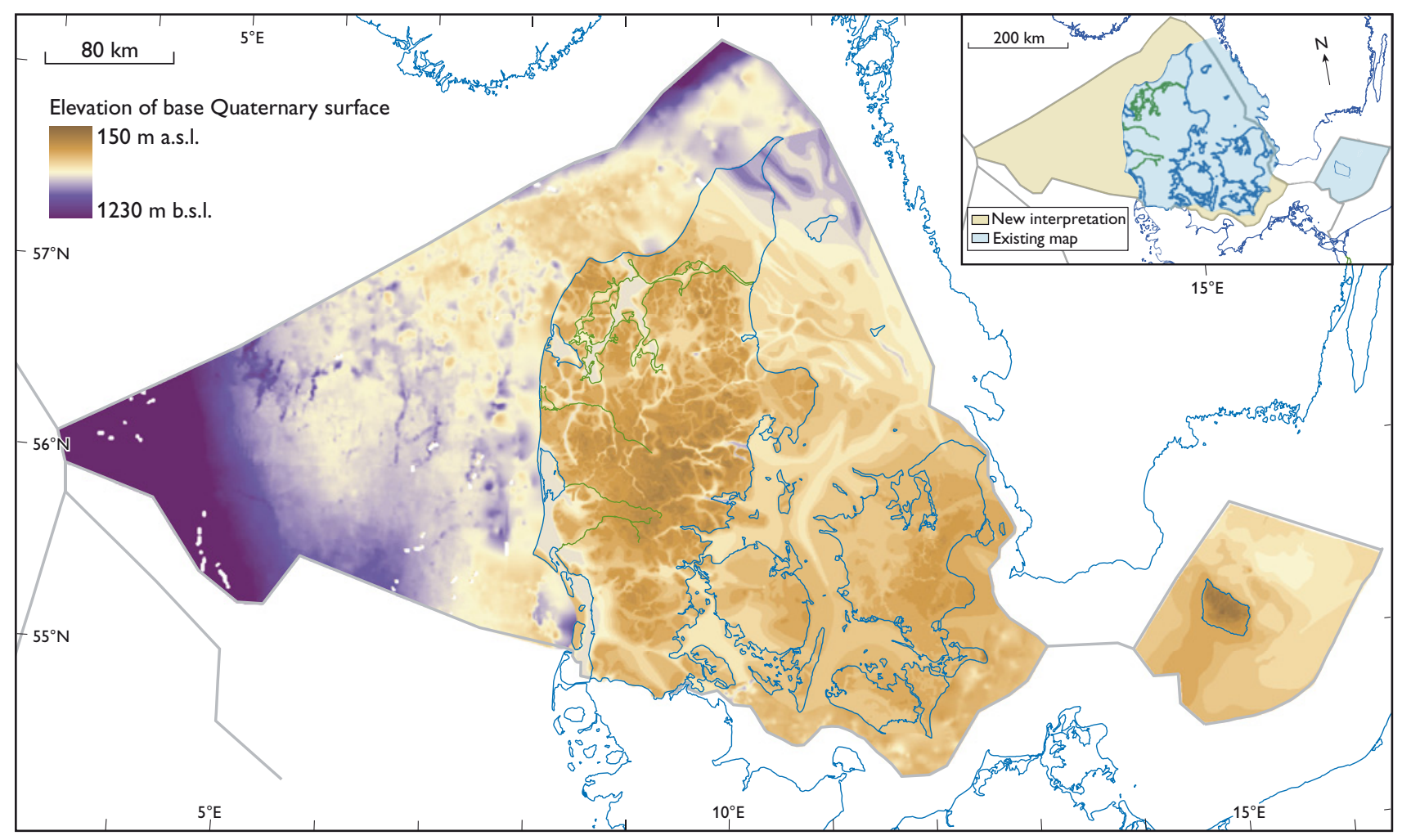

Fig. 4. Base Quaternary composite map. The map was created by merging the depth-converted new seismic mapping of the North Sea, Skagerrak and southern Bælthavet with an existing map of the Danish onshore, Kattegat and inner domestic marine areas (Binzer \& Stockmarr 1994) (see text for details).

E-W-trending tunnel valleys (pink on Fig. 3) extend to the Main Stationary Line (MSL; the Last Glacial Maximum stillstand line, e.g. Houmark-Nielsen 2007), indicating a late Weichselian impact on the base Quaternary surface in this onshore region, while the deeper N-S-trending tunnel valleys (light purple on Fig. 3) lie south and west of the MSL, suggesting a pre-Weichselian age.

\section{Acknowledgements}

Fugro-Geoteam and Danpec A/S are thanked for permission to use their reprocessed $2 \mathrm{D}$ seismic data.

\section{References}

Andersen, L.T., Hansen, D.L. \& Huuse, M. 2005: Numerical modelling of thrust structures in unconsolidated sediments: implications for glaciotectonic deformation. Journal of Structural Geology 27, 587-596.

Binzer, K. \& Stockmarr, J. 1994: Geological map of Denmark, 1:500 000. Pre-Quaternary surface topography of Denmark. Danmarks Geologiske Undersøgelse Kortserie 44, 10 pp., 2 maps.

Gradstein, F.M., Ogg, J.G. \& Smith A.G. (eds) 2004: A geological time scale, 610 pp. Cambridge: Cambridge University Press.
Håkansson, E. \& Pedersen, S.A.S. (eds) 1992: Geologisk kort over den danske undergrund. Varv. Map sheet 1. København: Varv.

Houmark-Nielsen, M. 2007: Extent and age of Middle and Late Pleistocene glaciations and periglacial episodes in southern Jylland, Denmark. Bulletin of the Geological Society of Denmark 55, 9-35.

Huuse, M. \& Lykke-Andersen, H. 2000: Over-deepened Quaternary valleys in the eastern Danish North Sea: morphology and origin. Quaternary Science Reviews 19, 1233-1253.

Huuse, M., Lykke-Andersen H. \& Michelsen, O. 2001: Cenozoic evolution of the eastern Danish North Sea. Marine Geology 177, 243-269.

Japsen, P., Bidstrup, T. \& Lidmar-Bergström, K. 2002: Neogene uplift of southern Scandinavia induced by the rise of the south Swedish dome. In: Doré, A.G. et al. (eds): Exhumation of circum-Atlantic margins: timing mechanisms and implications for hydrocarbon exploration. Geological Society Special Publication (London) 196, 183-207.

Klint, K.E.S. \& Pedersen, S.A.S. 1995: The Hanklit glaciotectonic thrust fault complex, Mors, Denmark. Danmarks Geologiske Unders $\emptyset$ gelse Serie A 35, 30 pp.

Rasmussen, E.S., Vejbæk, O.V., Bidstrup, T., Piasecki, S. \& Dybkjær, K. 2005: Late Cenozoic depositional history of the Danish North Sea Basin: implications for the petroleum systems in the Kraka, Halfdan, Siri and Nini fields. In: Doré, A.G. \& Vining, B.A. (eds): Petroleum geology: North-West Europe and global perspectives. Proceedings of the 6th Petroleum Geology Conference, 1347-1358. London: Geological Society.

Salomonsen, I. \& Jensen K.A. 1994: Quaternary erosional surfaces in the Danish North Sea. Boreas 23, 244-253.

\section{Authors' address}

Geological Survey of Denmark and Greenland, Øster Voldgade 10, DK-1350 Copenhagen K, Denmark. E-mail: tn@geus.dk 